\title{
Innovation in Food and Health: Study Into Challenges and Opportunities for Dutch Small and Medium Sized Enterprises
}

\author{
Joop Vree-van Straten ${ }^{1} \&$ Annet J. C. Roodenburg ${ }^{1}$ \\ ${ }^{1}$ HAS University of Applied Sciences, The Netherlands \\ Correspondence: Joop Vree-van Straten, HAS University of Applied Sciences, The Netherlands. Tel: \\ 31-73-692-3637. E-mail: joopvreevanstraten@gmail.com
}

Received: July 29, 2013 Accepted: November 15, 2013 Online Published: November 29, 2013

doi:10.5539/jfr.v3n1p28 URL: http://dx.doi.org/10.5539/jfr.v3n1p28

\begin{abstract}
This article focuses on the opportunities and challenges Dutch Small and Medium sized Enterprises (SMEs) in the food and beverage industry are facing with respect to innovation in food and health. An online questionnaire was developed to give an overview on attitudes and activities of SMEs with respect to innovation; their interest in trends, among which were health and wellbeing; and their view on logos as a possible way of communication. The questionnaire was held May 2011 with a response of $n=110$. Results show that innovation is important for SMEs: over $80 \%$ of the SMEs are innovating in products and over $60 \%$ in processes. The most appealing trends are: Health and wellbeing, 'Puur en Eerlijk' (Note 1) and sustainability. Of the SMEs 70-80\% indicate to have a current, and $85 \%$ a future interest in these trends. Furthermore $43 \%$ used the health logo on part of their product portfolio. Logos that communicate health and sustainability are most popular; $23 \%$ of the SMEs indicated not to be interested in the use of logos in general. In conclusion, the identified opportunities for innovation in food and health are: a large willingness to innovate and the increasing interest in the already appealing trend of nutrition and health. There is a moderate interest in (health) logos. Challenges are time, costs, knowledge on innovation in general and lack of specific knowledge on nutrition and health, and unclarities around use and added value (informative and increasing sales) of logos. Also, taste is considered as important as health and cannot be compromised.
\end{abstract}

Keywords: innovation, food, health, small and medium sized enterprises, challenges, logos

\section{Background}

Prevalence of obesity has doubled worldwide between 1980 and 2008 (Finucane et al., 2011). On average 17\% of people in OECD (Organization for Economic Co-operation and Development) countries are obese (Centraal Bureau voor de Statistiek [CBS], 2012). Dutch figures for 2010 state $66 \%$ and $44 \%$ of respectively men and women between 30 and 70 years of age are overweight, $14 \%$ of the men and $13 \%$ of the women are obese. In addition $13 \%$ of Dutch children are overweight and $7 \%$ are obese. Consequently $34 \%$ of men and $24 \%$ of women suffer from the metabolic syndrome: overweight with high blood cholesterol levels and high blood pressure related to a higher incidence of cardiovascular disease and some types of cancer (RIVM, 2011). This is a consequence of an unhealthy, sedentary life style and a diet containing too much energy, (high glycemic) sugars, (saturated and trans-) fatty acids and sodium, and concurrently low in fiber and unsaturated fatty acids (World Health Organization [WHO], 2004; Ludwig, 2011).

To reduce the prevalence of diet related chronic diseases, the World Health Organization (WHO) has recommended to limit the intake of sodium, sugar, saturated fatty acids and trans fatty acids in food and calls on the private sector to improve the food supply, by reducing levels of saturated fatty acids, trans fatty acids, free sugars and sodium in current products, introducing new products with better nutritional value and issue simple labeling to communicate the nutritional value to the consumer; thus making the healthy choice the easy choice (WHO, 2004). The Dutch government incorporated these recommendations in the 2011 health policy plan (Dutch Ministry of VWS, 2011) emphasizing on making the healthier choice easier through the use of healthy assortments and labels and stimulating the industry to innovate on healthy products.

The food and beverages sector is the largest industry in the Netherlands with 51 billion turnover and employing 118000 people. In the last three years it held around 4300 different companies with $98 \%$ being represented by small and medium sized enterprises (SMEs: 3-250 employees each). Of these SMEs 3087 companies were 
economical active, accounting for $43 \%$ turnover, $42 \%$ added value and $63 \%-67 \%$ employment of the Dutch food and beverage sector (market research institute EIM, 2012; CBS, 2011; Kamer, 2010). European figures are similar with about 300,000 SMEs representing $97-99 \%$ of the total food and beverages industry, responsible for $48 \%$ turnover and $48 \%$ added value and $63 \%$ employment in the food sector (Schmiemann, 2008; CBS, 2006).

The food industry is a large and traditional low-tech industry with low research and development (R\&D) budgets. The average R \& D budget for European food and beverage SMEs is $0.37 \%$ of overall revenue, which should at least double to become world leading (US 0.5\%, Japan 1.0\%) (FoodDrinkEurope, 2012). This is still low in comparison to the average 1.9\% in other sectors. Although not met, the European Council aimed in the Lisbon strategy (European Council, 2000) at an overall R\&D expenditure of 3\% gross domestic product (GDP) in 2010, which is now set for 2020. Two-thirds should be financed by the private sector and one third by the public sector. The Dutch government aims in her Top Sector policy for a R\&D expenditure of 2.5\% of GDP in 2020 (Dutch Government, 2012) and stimulate fast growing and beginning entrepreneurs with $€ 500$ million dare capital, stimulating and sharing the financial risks of innovation. Subsidies are essential because reducing the available subsidies would limit the innovation capacity for especially SMEs (Foreman-Peck, 2010).

A positive stimulus for innovation in food and health was the introduction of the healthy choice logo. In the Netherlands this logo was introduced in 2006 after a request from the Dutch government to the food industry to develop one simple logo to help consumers make healthy food choices and at the same time to stimulate the manufacturers to improve product composition for a more healthy positioning in its category. Since its introduction, the implementation of the health logo has been evaluated with respect to its effects on consumers (Healthy Choice, 2012) and producers (Vyth, Steenhuis, Roodenburg, Brug, \& Seidell, 2010). As incorporated in the Dutch health policy plan, the use of labeling and logos are subject in this study. In addition the WHO would like insight into a national prospect about constraints encountered in implementing the healthy strategy and measures how to overcome (WHO, 2004). In line with the national and WHO interest the following research questions are formulated:

- What is the attitude of SMEs with respect to innovation in general?

- What are the opportunities and challenges that SMEs encounter when innovating in food and health?

- What is the opinion of SMEs about usefulness, benefit and acceptance of logos as a consumer communication tool (such as "Choices" logo)?

Therefore this paper reports on the attitudes and reported activities of SMEs in the food and beverage industry with respect to innovation; their interest in trends, among which were health and wellbeing; and their view on logos as a possible way of communication. These are keys to uncover the opportunities and challenges SMEs meet when innovating in food and health.

\section{Methods}

\subsection{Development of Questionnaire}

A qualitative study, consisting of a desk study and six open interviews with specialists in nutrition, food science, innovation, representatives from industry and from the foundation of the Dutch health logo (Dutch: Stichting Ik Kies Bewust), was performed to gain insight in the trends, opportunities and challenges SMEs encounter concerning innovation in food and health. Based on this information a questionnaire was developed following the theory of Baarda and de Goede (2006). The questionnaire has a funnel build up. Participants were asked about their roll in their company, their company's attitudes, motivations, knowledge, behavior, challenges and opportunities concerning innovation, healthy food and logos.

\subsection{Selection and Approach}

The list from the Dutch Chamber of Commerce (Dutch: Kamer van Koophandel) consists of 2563 companies active in the sectors of food production and food processing industry. From this list a pre-selection is made by excluding companies smaller than 10 FTEs (employees, full time equivalent). This was done for practical reasons and because a considerable percentage of the "micro" sized companies ( 1 or 2 FTEs) are not economically active (Kamer van Koophandel, 2011). Of the remaining 919 companies > 11 FTEs, contact details for a person responsible for innovation could be collected by phone for 750 companies. These 750 companies were invited via email to fill out the online questionnaire on Thesistools (Thesistools, 2011). Two reminder emails were sent to increase the response. 


\section{Results}

\subsection{Response}

Of the 750 invitations, 110 companies filled out the online questionnaire. Figure 1 shows the distribution per branch. There were 7 companies with more than 250 FTE, 41 companies with 50-250 FTEs, 54 companies with 11-50 FTEs, 5 companies with 3-10 FTEs and three with less than 3 FTEs. Overall 17 companies had a turnover higher than 50 million Euro. A total of 18 companies did not match the criteria for SMEs as described by the European Commission (2003/361/EC) (European Commission, 2009), because they have more than 250 FTEs or a turnover higher than 50 million Euro. Their data are excluded from the results. From the remaining 92 questionnaires, some of the answers were missing. Due to these missing data sets, the number of respondents per topic may differ. In general, $43 \%$ of the responses to the questionnaires $(n=92)$ were provided by workers in the rank of managing director, $15 \%$ by representatives from research and development, $8 \%$ by marketing and $34 \%$ by other functions in the company. Furthermore, $38 \%$ of the respondents reported to have full innovation responsibility and 58\% were partly responsible, but actively involved in innovation. In addition, $80 \%$ of the respondents are involved in production of end fabricates, $12 \%$ in semi-finished products and $8 \%$ in raw ingredients.

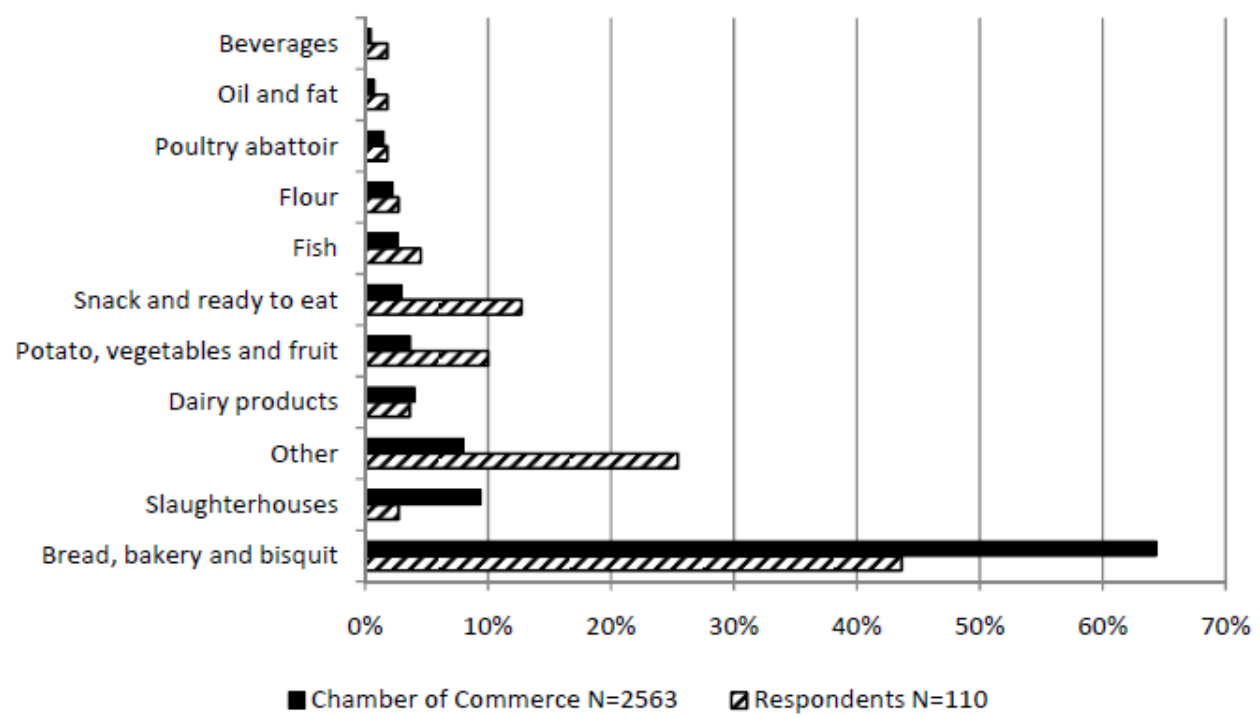

Figure 1. Representativeness per branch of the sample survey. Of 2563 Dutch food companies, 750 companies were addressed of which 110 SMEs returned the questionnaire. The total percentage may excess $100 \%$ because some companies are active in more than one branch

\subsection{Innovation Strategies and Trends}

Ninety percent (90\%) of all SMEs indicate that innovation is important or very important (Table 1), none of the companies indicates that innovation is not important. However, less than half (i.e. 47\%) of the respondents certified their company as (very) innovative and $9 \%$ as limited innovative, whereas no respondent certified their company as very limitedly innovative. Innovation is mostly applied to improve products (81\%) and processes $(69 \%)$. Entering new markets $(45 \%)$ is a less often mentioned objective. When asked about their product innovation activities over the past 3 years (Table 1), renovation, which is innovation of existing products to comply with new criteria, has been applied by $75 \%$ of SMEs, and is thus the main target of innovation. Fifty one percent $(51 \%)$ of the SMEs conducted restoration (bringing existing or old products again into the market). Less than a quarter of respondents reported to innovate to create totally new products (radical innovation). When asked about their process innovation activities over the past 3 years, introduction of new products is most often mentioned $(65 \%)$ followed by cost reduction. When questioned about their expectations for the future, cost reduction, sustainability and new technologies are growing areas where SMEs intend to innovate on. 
Table 1. Innovation in Dutch food SMEs: opinions, types of innovation and targets

\begin{tabular}{ll}
\hline & \% of companies \\
\hline Opinion (N=81) & \\
Innovation is (very) important & $90 \%$ \\
My company is (very) innovative & $47 \%$ \\
My company is (very) limitedly innovative & $9 \%$ \\
Type of innovation (N=83) & \\
Product innovation & $81 \%$ \\
Process innovation & $69 \%$ \\
New markets & $45 \%$ \\
Target of product innovation (N=83) & \\
Renovation (innovation on existing products to comply with new criteria) & $75 \%$ \\
Restoration (bringing existing or old products again into the market) & $51 \%$ \\
Radical innovation (creation of new products) & $23 \%$ \\
Target of process innovation (N=83) & \\
Introduction new products & \\
Cost reduction & $65 \%$ \\
Increase production capacity & $57 \%$ \\
Sustainability & $46 \%$ \\
New technologies & $27 \%$ \\
\hline
\end{tabular}

SMEs were asked to indicate on a five point scale to which extent they are interested in seven different trends and to what extent they follow each trend. (Figure 2 provides information on each. The retailer's own positioning 'Puur en Eerlijk'(Note 1), health and wellbeing and sustainability are the most popular trends followed by convenience and traditional craft production. In comparison to the other trends, Organic and Regional produce are the least popular. The percentage of companies that follows a trend is generally lower when compared to the percentage that is interested in a trend. This differs most for sustainability and least for convenience.

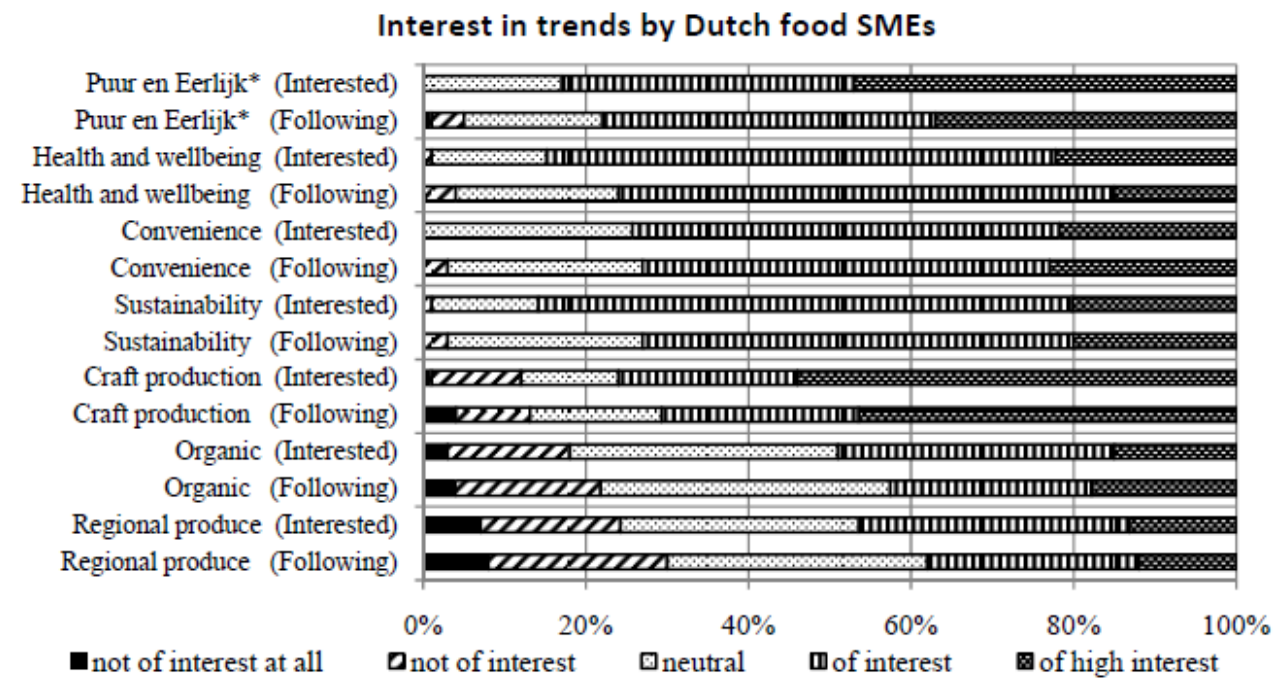

Figure 2. For Dutch Food SMEs $(\mathrm{N}=87)$ it is indicated how "interested" they are and to what extent they are "following" trends. * 'Puur en eerlijk' is a Dutch retailers own positioning associated with organic, agriculture, fair-trade, sustainable fish \& meat and ecological production (Albert Heijn). The results are put in order of increasing interest 
The participants were requested to what extent they agree with 13 propositions (p1-13) on innovation in general and related to health on a five point scale. In Figure 3 it is shown that innovation is necessary for a good competitive market position (p1). However, innovation requires much time and knowledge (p3 and 4). The majority of SMEs think that innovation results in a better margin of profit (p5). Less than half of the SMEs agree that innovation is expensive against $14 \%$ that disagree with this proposition (p7). Altogether, most SMEs think innovation is not only do-able for the larger companies (p13). The propositions about logos (p9-12) show great variation in opinions about the usability and functioning of logos, manifested by similar sizes of agreements and disagreements on both sides of the neutral group. The price of logos is okay to expensive (p8). Most (86\%) SMEs believe that producing healthy food is a requisite for the company's future (p2). However, taste is seen by $56 \%$ of the SMEs as more important to consumers than health (p6).

\section{Opinion of Dutch food SMEs about innovation}

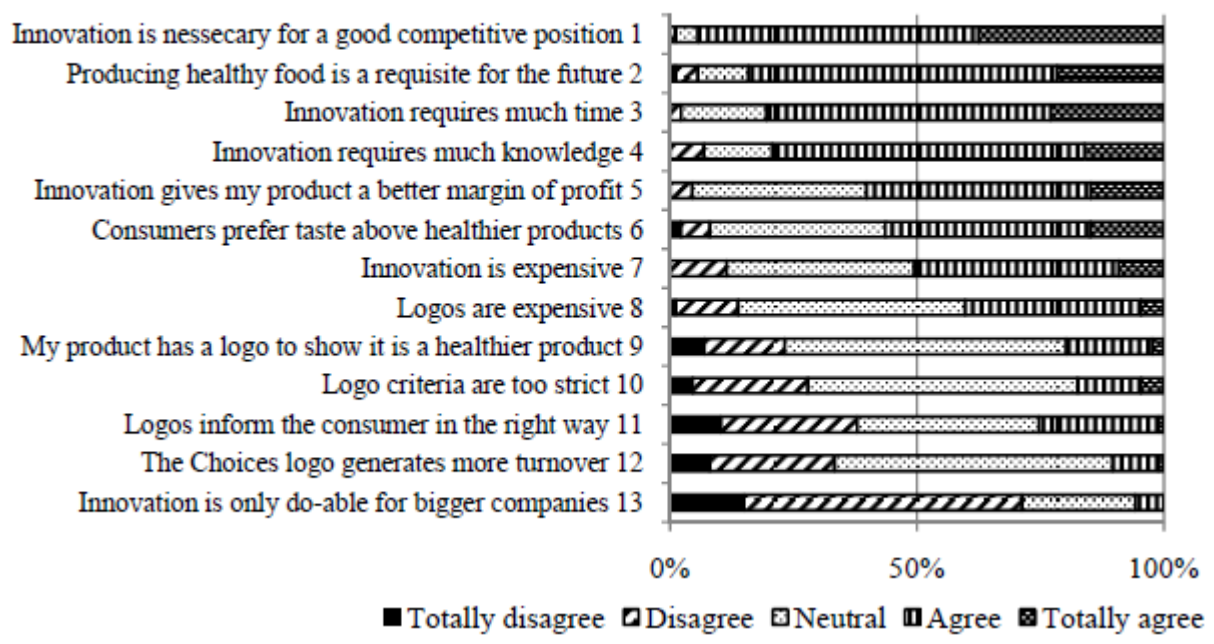

Figure 3. Opinions of Dutch food SMEs about 13 statements related to innovation in general or related to health $(\mathrm{N}=86-88)$. Level of agreement was indicated on a five point scale. The propositions in the figure are, from bottom to top, put in order of increasing agreement

\subsection{Knowledge and Innovation in Food and Health:}

One of the anticipated challenges in innovation is knowledge: More than $80 \%$ of SMEs agree with the proposition that innovation requires much knowledge (Figure 3, p4). In Table 2 it is shown that almost all companies acquire knowledge through external expertise. With respect to education, brief forms of education such as self-study, seminars and courses are most popular. There was no difference between acquiring knowledge on innovation "in general" and knowledge on innovation "specifically related to health" (data not shown). Considering company size, availability of internal knowledge is scarcer for smaller companies as compared to companies with more than 50 FTEs. The smaller companies $(<50 \mathrm{FTEs})$ also make less use of the different types of education (data not shown). 
Table 2. In-company knowledge of Dutch food SMEs (Small and Medium sized Enterprises) and ways of obtaining knowledge for innovation in general

\begin{tabular}{lc}
\hline Source of knowledge within companies & $\%$ SMEs \\
\hline Research \& Development & $44 \%$ \\
Marketing & $24 \%$ \\
Production & $52 \%$ \\
No specialists & $31 \%$ \\
External expertise & $97 \%$ \\
Type of education for obtaining knowledge for innovation & \\
Fulltime education & $4 \%$ \\
Part-time education & $18 \%$ \\
Courses & $43 \%$ \\
Seminars & $33 \%$ \\
Self-study & $32 \%$ \\
No specific course & $37 \%$ \\
\hline
\end{tabular}

\subsection{Application of (Health) Logos}

The SMEs have been questioned on their current and preferred use of different logos on pack. In Figure 4 and 5 the results are shown. There is a substantial $(20-40 \%)$ current usage of the different logos. Considering all logo themes (Figure 5), environmental and sustainability logos are most applied by the respondents (40\%), followed by product specific (such as allergen) logos (32\%) and health logos (30\%). The opinion that logos are expensive (Figure 3, p8) is largely supported. With respect to health logos specifically, SMEs reported that they are not convinced the Choices health logo will generate more turnover (Figure 3, p12). Only end products can carry a health logo. $43 \%$ of respondents producing end products have a health logo on part of their portfolio (Figure 4). $57 \%$ has no health logo and $23 \%$ is not interested in a health logo. $96 \%$ of SMEs are of the opinion that their products are healthier than the products of their competitors.

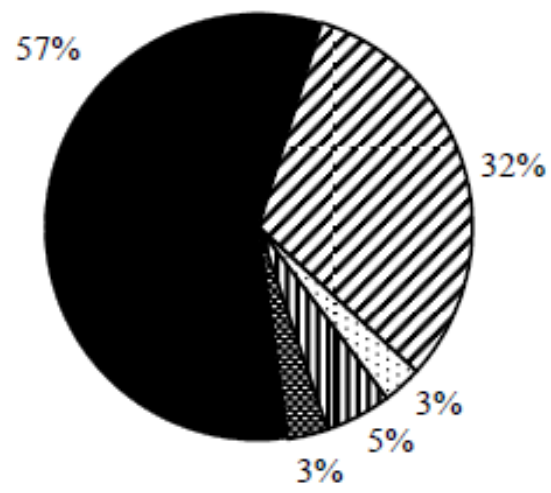

- No health logo

a Healthlogo on $10-25 \%$ portfolio

GHealthlogo on $25-50 \% \%$ portfolio

DHealthlogo on $50-75 \%$ portfolio

图Healthlogo on $75-100 \%$ portfolio

Figure 4. Percentage of end producing companies that uses a health logo classified to the percentage of their portfolio carrying the logo. $\mathrm{N}=79$ 


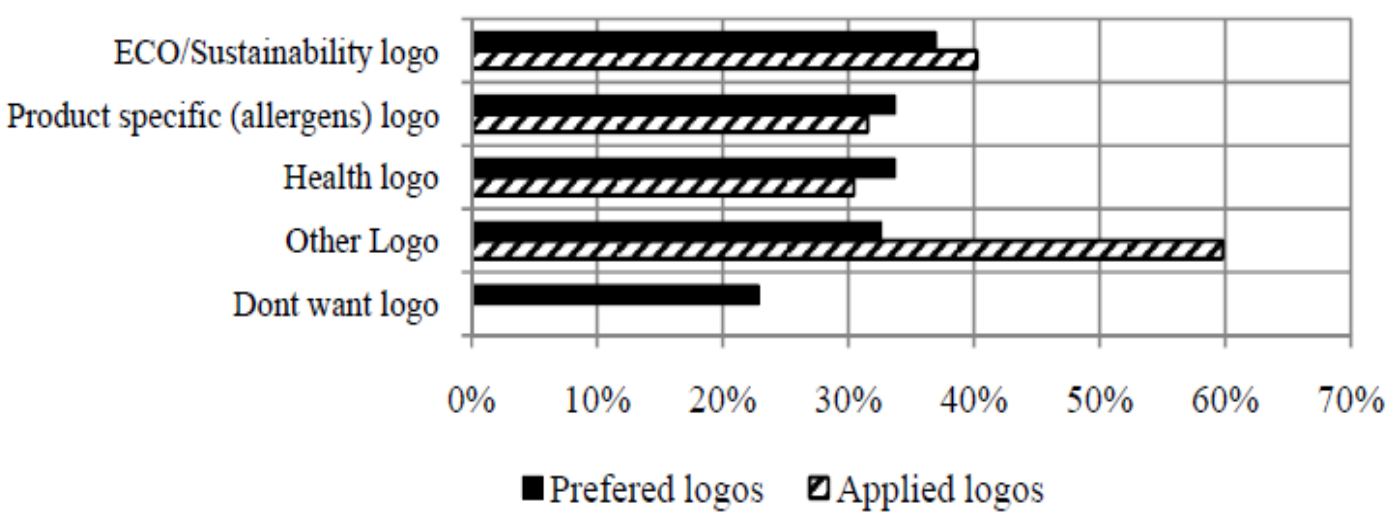

Figure 5. Percentage of Dutch food SMEs currently applying logos and their future interest in logos. N=79 More than one answer per company is possible. Data for religion (kosher, halal) and regional (locally sourced) are added to "Other logo"

\section{Discussion}

This study aimed to clarify the challenges and opportunities SMEs encounter when innovating in food and health. Based on a qualitative study, interviewing six specialists in the field of nutrition, food science, innovation, logos and representatives of the industry, an online questionnaire was developed to measure their opinion and attitude on innovation in food and health and the use of logos. Generally, the results show that innovation is important for SMEs. The main challenges are limited time, money and knowledge on innovation in general and lack of specific knowledge on nutrition and health. There is however a large interest in health as a trend. While little less than half of the responders are using a health logo on part of their product portfolio the functionality of logos is overall unclear, such as: whether they increase sales, or are informative enough for consumers.

\subsection{Responses and Representation}

Figure 1 shows the number of respondents in every branch, reflecting the actual distribution, only slaughterhouses are underrepresented. A pre-selection for SMEs of 11-250 FTEs was made in the list from the Dutch Chamber of Commerce. Despite this pre-selection, the information given in the questionnaire did not always correspond with the information from the Dutch Chamber of Commerce about company size and turnover. Companies that did not fit the definition for SME $(<250 \mathrm{FTE},<50$ million Euro turnover $)$ were excluded from the datasets. The micro and small sized companies were kept in the dataset.

\subsection{Innovation Motives and Trends}

Generally, the most appealing trends are health \& wellbeing, 'Puur en Eerlijk' (Note 1) and sustainability. Of the companies $70-80 \%$ follow these trends, almost $85 \%$ are interested in these trends. Unlike convenience and sustainability, organic and regional produce cannot be practiced in different degrees. They ask for full commitment, which probably explains the higher scores in 'not of interest (at all)' for these trends. 'Puur en Eerlijk' (Note 1) covers a broad spectrum, including sustainability or organic. Thus the popularity of this trend is likely to overlap with other trends. Interesting is that this theme is set in the market by a major Dutch retailer (Albert Heijn, 2012), and leads to a very high interest of the food producing sector. The interest and commitment to one of the trends is overall high. However it was also noted from the data that perception may hold taste as equally or more important than health.

Results also show that innovation is important for Dutch food SMEs. This is illustrated by their innovation activities: more than $80 \%$ innovates in products and more than $60 \%$ in processes. When comparing this study to a survey of the Dutch Central Bureau for Statistics (biennially survey, 2006-2008, 1285 respondents (CBS, 2011)), the percentage of SMEs that innovate to introduce new products is $74 \%$ (CBS 2006-2008), which is slightly higher than the $64 \%$ in the present study, reflecting the period 2008-2011. Instead renovation (to innovate existing products to comply with new criteria) was 53\% in 2006-2008 (CBS, 2011) which is lower as compared to $75 \%$ in this study (2008-2011). The percentage of companies that innovate to increase production capacity was reported to be $62 \%$ in $2006-2008$ (CBS, 2011) which was higher when compared to the present study (46\%). The percentage that innovated for cost reduction was comparable in the two studies: $55 \%$ (CBS, 2011 ) and $57 \%$ (this study), and is likely to increase: $70 \%$ thinks that in the future cost reduction will be one of 
the reasons for innovation. Another study, the Top Topics FMCG 2012 survey (500 industrial and 77 retail respondents, mainly from $>250$ FTE companies (FNLI, 2011)) pointed out that strong innovation is necessary to escape price pressure and assortment rationalization, enforced by the larger retailers. The competition was smaller than retailers claim, lowering the need for innovation for the company to survive, but increased the chance of successful introductions (FNLI, 2011).

\subsection{Challenges}

The challenges identified in this study are limited time, money and knowledge on innovation in general and lack of specific knowledge on nutrition and health. Innovation is considered expensive and time consuming. This is also confirmed in the SMEPOL study and by the Food and Nutrition Delta (FND, 2012; Nauwelaers \& Wintjes, 1999). Entering innovation is hampered by legislation, price pressure by both raw materials and retailers, especially for SMEs (Aslesen, 2008; Nauwelaers \& Wintjes, 1999; market research institute EIM, 2012). Especially the low-tech food industry has a relatively small R\&D budget (FoodDrinkEurope, 2012) which should grow according the EU-council (European Council, 2002; European Union, 2006). Low budgets hinder innovation because there are less means for personnel and training (European Union, 2006). Innovation in general as well as specifically innovations in food and health require much knowledge. That knowledge was internally mostly found at research and development and production departments, but nearly all companies turn to external parties to replenish the necessary knowledge (CBS, 2011). The study from CBS indicated that suppliers and clients were the main sources followed by conferences, competitors, branch organizations and literature (CBS, 2011). Another online survey (November 2011-January 2012, 129 respondents) by the Food and Nutrition Delta (FND, 2012), mapping the largest challenges companies face when making a commercial success of an innovation, further specified the knowledge deficiency in lack of competence in: technology, production, market- and marketing knowledge, and jurisdiction (e.g. protection of intellectual properties). Other major challenges listed by the FND study are insufficient pace in innovation and commercialization and lacking finance for innovation to market introduction. Companies are afraid that their innovations are copied shortly after bringing it to the market (FNLI, 2011). Feedback from SMEs during the SME conference (Food \& Nutrition, 2012), presenting the results from this study, confirms and upholds previous mentioned challenges for SMEs: accessibility of investors, especially with up-scaling; finding and applying legislation for new-category products; the knowledge to bring the product to the market; positioning in the market; and uncertainty of consumer acceptance of innovative products and consumer demand.

\subsection{Support for SMEs}

National and European subsidies are available for innovations in food and health (8137 million Euro for 2007-2013 (European council, 2012)), stimulating companies and reducing the risks. The European Technology Platform (ETP), erected in pursuit of the Lisbon Strategy (European Council, 2000), supports the entire food industry by delivering long term visions of the sector, creating strategies and supporting in management, fundraising and training (European council, 2012). ETP works according the Framework Program 7 (FP7, 2007-2013) with a budget of 727 billion euro, divided over programs to enhance co-operation, ideas, training and innovation capacity. These are according to the SMEPOL study (combining 11 studies about regional innovation policies in Europe, (Nauwelaers \& Wintjes, 1999)) the most important support issues: financial; technology and technical knowhow; qualifications and personnel; market access and -information; time constraints, organization and strategic capabilities. But as these points keep coming back as the main challenges Dutch food SMEs meet when innovating (CBS, 2011; FND, 2012; FNLI, 2011), questions are raised about the reach, visibility, accessibility and effectiveness of the national and European innovation support programs. Innovation however, according to the SMEs, is not only do-able for large companies and they are able to find external knowledge outside their companies. For 2012, 30 million Euro innovation subsidies of the FP7 FAFB (Food, Agriculture \& Fisheries, and Biotechnology) program are assigned to Dutch companies and institutes of which 5 million to Dutch SMEs in the agro-food sector. Through specially assigned intermediating independent institutes as the FND and the governmental Agentschap NL, Dutch companies become increasingly better in finding, qualifying for and receiving subsidies (Innofood, 2012).

\subsection{Opportunities for Innovation in Food and Health}

This study showed that health and wellbeing is among the most popular trends in food production (Figure 2). We also found that taste is more important than health. This is in line with the study of Verbeke (Verbeke, 2006) who showed that companies think consumers are not willing to compromise taste over health. According to Verbeke the consumer perception of the importance of food for health is increasing, but the belief in health benefits from functional foods decreases, resulting in a lower willingness to compromise on taste. However, availability of 
healthy food is climbing on the global (World health Organization, 2004), European (Whitelegg, Weber, Hofer, \& Polt, 2008) and national (Dutch Ministry of VWS, 2011) agenda. Health is also becoming more a priority topic as SMEs see producing healthy food as a prerequisite for their company's future. Health is, according to Top Topics FMCG 2012, the fastest growing priority topic for companies and retail, respectively from $27 \%$ and $16 \%$ in 2011 to $31 \%$ in 2012, surpassed in importance only by: the relation between industry and retail; product, brand and formula range; and consumer marketing (FNLI, 2011). The common interest in healthy food creates a base opportunity for collaboration on this topic between industry and retail. Companies consider health to contribute to a higher added value of the product than taste (FND), and they think innovation gives their products also a better margin of profit (this study), so health becomes an economically attractive trend.

\subsection{Logos}

Of the responding companies, $43 \%$ used the health logo on part of their product portfolio. Logos that communicate health and sustainability are most popular. However $23 \%$ of the participants indicated not to be interested in the use of logos in general. SMEs seem hesitant to use logos to inform the consumer about their product being the healthier choice, although $96 \%$ declares their product is healthier than their competitors' product. $28 \%$ uses a health logo, but only $20 \%$ uses the logo to show the product is healthier. There is a large variation in how SMEs think about logos. The neutral response group, for all propositions about logos (Figure 3: p8-12), form the largest groups. Especially, the proposition about logos informing the consumer in the right way about products (Figure 3: p11) resulted in a wide distribution of answers. It is not straightforward for the producer whether the use of the healthy choice logo increases sales and if logos are informative enough to the consumer. Also in literature there is no consensus whether front of pack nutrition labeling is more effective than descriptive labeling as provided by caloric information (Vyth, 2012). Ellis Vyth evaluated the Dutch choices logo (Vyth, 2012) and found that the actual use of the logo was low. The most important buying motives are price, taste and convenience over health. Health motivated consumers use the choices logo more and buy more products with the choices logo than other consumers. Hedonic motivated consumers are less likely to use the logo. The consumers' exposure to the logo increased in the past years, though the impact could be further improved by better explanation of the logos' function and that it is supported by the government and scientific community (Vyth et al., 2009; Vyth et al., 2010). The interest in the future use of logos does not differ much from the current usage (Figure 5), however it is remarkable that the future interest for the diverse smaller logos is a factor two smaller than current usage (Figure 5, Other logo). This could be a result of the proliferation of logos with new rules and more unclarities around the use and benefits of the logos.

In summary, the present study shows that Dutch food SMEs acknowledge the importance of innovation for their market position and consider themselves to be able to innovate. Challenges in innovation are the high investments in terms of time, knowledge and money, but with the better supporting infrastructure in the Netherlands, Dutch food SMEs become increasingly better in finding, qualifying for and receiving subsidies and support. Innovation gives SMEs a better margin of profit. Cost reduction is expected to become one of the most important future innovation drivers. Sustainability and health are the fastest growing trends and are the number one and two trends SMEs like to follow. Health is even evolving from a trend to a product criterion; however taste may not be compromised over health. Most SMEs think a healthy product is a pre-requisite for their companies' future. Together with the high urge from the (inter)national agendas, this creates great stimulants for innovations in food and health. In communication to the consumer the reason to use the healthy choice logo is not always to advocate the products healthier positioning. Opinions about the use and functionality of logos vary significantly between SMEs.

\section{Acknowledgements}

From this place we like to thank the participating companies who made this study possible and the two students, Britt van Mensvoort and Lukas Schraven who executed this study, together with their supervisors Paula Hehewerth and Domingo Loth; And Ingrid Steenhuis for her support on the questionnaire.

\section{References}

Albert Heijn. (n.d.) (2012). Puur en Eerlijk. Retrieved May 4, 2012, from http://www.ah.nl/puureneerlijk

Aslesen, W. H. (2008). Prospective innovation challenges in the food and drink sector. Europe Innova. Retrieved from http://ryby.rsi.org.pl/dane/download/perspektywy_sektora_-_food_and_drink.pdf

Baarda, D. A., \& de Goede, M. P. M. (2006). Basisboek Methoden en Technieken (4th ed.). Groningen: Noordhoff Uitgevers B.V. 
Centraal Bureau voor de Statistiek. (2006). Statline: Innovatie bij bedrijven; bedrijfstakken/branches (SBI'93), 2004-2006 [key figures]. from http://statline.cbs.nl/StatWeb/publication/?DM=SLNL\&PA=71788ned\&D1=0-1,13,78-79,262,310,317\&D2 $=0-1,17,29-33 \& \mathrm{VW}=\mathrm{T}$

Centraal Bureau voor de Statistiek. (2011). Statline:Bedrijven naar economische activiteit (SBI 2008, 2006-2010). Retrieved from http://statline.cbs.nl/StatWeb/publication/?DM=SLNL\&PA=80233NED\&D1=1-8\&D2=67,103\&D3=3-4\& $\mathrm{HDR}=\mathrm{G} 2 \& \mathrm{STB}=\mathrm{G} 1, \mathrm{~T} \& \mathrm{VW}=\mathrm{T}$

Centraal Bureau voor de Statistiek. (2012). Aandeel inwoners met ernstig overgewicht in Nederland lager dan in andere OESO-landen. Retrieved from http://www.cbs.nl/nl-NL/menu/themas/gezondheid-welzijn/publicaties/artikelen/archief/2011/2011-3514-w m.htm.

Dutch Government. (2012). Samenvatting innovatiecontract Topsector Agro \& Food. Retrieved from http://www.rijksoverheid.nl/documenten-en-publicaties/kamerstukken/2012/04/02/samenvatting-innovatiec ontract-topsector-agro-food.html

Dutch Ministry of VWS. (2011). Landelijke nota gezondheidsbeleid 'Gezondheid dichtbij'. Retrieved from http://www.rijksoverheid.nl/documenten-en-publicaties/notas/2011/05/25/landelijke-nota-gezondheidsbelei d.html

European Commission. (2009). Small and medium-sized enterprises (SMEs). Retrieved from http://ec.europa.eu/enterprise/policies/sme/files/sme_definition/sme_report_2009_en.pdf

European Commission. (2012). Research and innovation. Retrieved from: http://ec.europa.eu/research/fp7/index_en.cfm

European Council. (2000). Lisbon European council 23 and 24 march 2000, presidency conclusions. Retrieved from http://www.europarl.europa.eu/summits/lis1_en.html

European Council. (2002). Presidency Conclusions-Barcelona, 15 and 16 March 2002. Retrieved from http://www.consilium.europa.eu/ueDocs/cms_Data/docs/pressData/en/ec/71025.pdf

European Union. (2006). State-aid. Official Journal of the Europian Union, C323/1-26.

Finucane, M. M., Stevens, G. A., Cowan, M. J., Danaei, G., Lin, J. K., Paciorek, C. J., ... Ezzati, M. (2011). National, regional, and global trends in body mass index since 1980: Systematic analysis of health examination surveys and epidemiological studies with 960 country-years and 9.1 million participants. $\mathrm{http}: / / \mathrm{dx}$.doi.org/10.1016/S0140-6736(10)62037-5

FND. (2012). Food and nutrition delta general questionairre. Retrieved from http://www.foodnutritiondelta.nl/images/export\%20van\%20enquete.pdf

FNLI. (2011). Top topics FMCG 2012. Retrieved from http:/www.fnli.nl

Food \& Nutrition. (2012). MKB-onderzoek Gezond innoveren: Tijd, geld en kennis nodig. Food \& Nutrition, 4(1), $42-43$.

Food Drink Europe. (2012). EU Innovation Union Flagship Communication and Ïnnovation Union”for EU Food\&Drink industry. Retrieved from http://www.fooddrinkeurope.eu/S=0/news/press-release/ciaa-welcomes-eu-innovation-union-flagship-com munication-and-calls-for-an-i/

Foreman-Peck, J. (2010). Effectiveness and efficiency of SME innovation policy. http://dx.doi.org/10.1007/s11187-012-9426-z

Healthy Choice. (2012). Healthy Choice. Retrieved from http://www.choicesprogramme.nl

Innofood. (2012). Innofood Nieuws. $\quad$ Retrieved from http://www.innofood.org/nl/nieuws/7023/nederlandse-agro-food-en-biotech-presteren-goed-in-subsidies-kp 7.html

Kamer van Koophandel. (2010). branchewijzer. Retrieved from: http://www.kvk.nl/ondernemen/brancheinformatie/branchewijzer/

Kamer van Koophandel. (2011). Cijfers Handelsregister. Retrieved from http://www.kvk.nl/over-de-kvk/over-het-handelsregister/cijfers-handelsregister/ 
Ludwig, D. S. (2011). Technology, Diet and the burden of chronic disease. http://dx.doi.org/10.1001/jama.2011.380

Market research institute EIM. (2012). Knowledge Web on SMEs and Entrepreneurship. Retrieved from http://data.ondernemerschap.nl/webintegraal/userif.aspx?selectdataset=14

Nauwelaers, C. A. \& Wintjes, R. (1999). SME policy and the regional dimension of innovation: towards a new paradigm for innovation policy? Maastricht: University of Maastricht.

RIVM. (2011). RIVM Rapport 260152001/2011 Nederland de maat genomen. Retrieved from http://www.nationaalkompas.nl/object_binary/o13231_Nederland-de-Maat-Genomen.pdf

Schmiemann, M. (2008). Industry, trade and services, eurostat Statistics in focus 31/2008. Retrieved from http://epp.eurostat.ec.europa.eu/cache/ITY_OFFPUB/KS-SF-08-031/EN/KS-SF-08-031-EN.PDF

Thesistools. (2011). Thesistools. Retrieved from www.thesistools.com

Verbeke, W. (2006). Functional foods: Consumer willingness to compromise on taste for health? http://dx.doi.org/10.1016/j.foodqual.2005.03.003

Vyth, E. L., Steenhuis, I. M., Mallant, S. F., Mol, Z. L., Brug, J., Temminghoff, M., ... Seidell, J. C. (2009). A front-of-pack nutrition logo: A quantitative and qualitative process evaluation in the Netherlands. http://dx.doi.org/10.1080/10810730903204247

Vyth, E. L., Steenhuis, I. M., Roodenburg, A. J. C., Brug, J., \& Seidell J. C. (2010). Front-of-pack nutrition label stimulates healthier product development: a quantitative analysis. http://dx.doi.org/10.1186/1479-5868-7-65

Vyth, E. L. (2012). Evaluation of a front-of-pack nutrition label. Effects on consumer behavior, product development and public health. Amsterdam: E. L. Kroonenburg-Vyth. Retrieved from http://hdl.handle.net/1871/33240

Whitelegg, K. W., Weber, M., Hofer, R., \& Polt, W. (2008). Strategic Governance of R\&D Related Policies. Retrieved from http://erawatch.jrc.ec.europa.eu/erawatch/opencms/information/reports/countries/eu/report_mig_0012

World Health Organization. (2004). Technical Reports Series 916: Global Strategy on Diet, Physical activity and health. ISBN-10 9241592222. Retrieved from http://www.who.int/topics/diet/en

\section{Notes}

Note 1. 'Puur en eerlijk' is a Dutch retailers own positioning associated with organic, agriculture, fair-trade, sustainable fish \& meat and ecological production (Albert Heijn). Its straight translation is Pure and Fair.

\section{Copyrights}

Copyright for this article is retained by the author(s), with first publication rights granted to the journal.

This is an open-access article distributed under the terms and conditions of the Creative Commons Attribution license (http://creativecommons.org/licenses/by/3.0/). 